\title{
Monsoonal Influence on Evapotranspiration of the Tropical Mangrove Forest in Northeast India
}

\author{
Dipnarayan Ganguly, Raghab Ray, Natasha Majumder, Chumki Chowdhury, \\ Tapan Kumar Jana \\ Department of Marine Science, Calcutta University, Kolkata, India \\ Email: tkjana@hotmail.com
}

Received 14 April 2014; revised 12 May 2014; accepted 7 June 2014

Copyright (C) 2014 by authors and Scientific Research Publishing Inc. This work is licensed under the Creative Commons Attribution International License (CC BY). http://creativecommons.org/licenses/by/4.0/

(c) (i) Open Access

\begin{abstract}
Evapotranspiration (ET) is an important part of the water cycle. This study reports on the monsoonal influence on the temporal variation in evapotranspiration of an extremely water conservative and salinity stressed tropical mangrove forest at the land-ocean boundary of northeast coast of India. The magnitude and dynamics of evapotranspiration (ET) exhibited seasonality dominated by monsoon and evaporation rate was greater $\left[0.055 \pm 0.015 \mathrm{~g} \cdot \mathrm{m}^{-2} \cdot \mathrm{s}^{-1}\right)$ during the monsoon than in pre-monsoon $\left(0.049 \pm 0.018 \mathrm{~g} \cdot \mathrm{m}^{-2} \cdot \mathrm{s}^{-1}\right)$ and post-monsoon $\left(0.044 \pm 0.012 \mathrm{~g} \cdot \mathrm{m}^{-2} \cdot \mathrm{s}^{-1}\right)$. Seasonal difference in evapotranpiration was mostly due to fluctuation of canopy resistance, which was the minimum during monsoon when relative humidity was greater than in the dry season (pre- and post-monsoon) and deficiency of water supply $(E T \approx E T e q)$ was minimum. Evapotranspiration in the Sundarban mangrove ecosystem is the predominant biophysical processes that recycles $67.7 \%$ of total precipitation annually to the atmosphere, and has significant monsoonal influence.
\end{abstract}

\section{Keywords}

Canopy Resistance, Evapotranspiration, Hydrological Cycle, India, Mangrove Forest, Monsoonal Cycle

\section{Introduction}

Water vapour plays an important role in the hydrologic cycle, which describes the storage and movement of water between the biosphere, atmosphere, lithosphere, and the hydrosphere. The loss of water from plant cells to the atmosphere by vaporization is called transpiration. More than $80 \%$ of the water that enters plants through 
their roots returns to the atmosphere through this process [1]. Low water vapour pressure in the air relative to that inside the leaves is the major driving force for water loss from leaves, which drives the movement into leaves and in turn drives movement into plant roots. Evapotranspiration is the main biophysical process that maintains the availability of water vapour in the atmosphere. Over the entire land surface of the globe, rainfall averages around $750 \mathrm{~mm} \cdot \mathrm{y}^{-1}$, of which some two third is returned to the atmosphere as evapotranspiration, making evapotranspiration the largest single component to study the terrestrial hydrological cycle [2].

The importance of evapotranspiration (ET) in the hydrologic cycle generally increases with increasing aridity [3]. In arid and semi-arid climates, ET often consumes a large part of precipitation and the amount and timing of ET can strongly affect stream flow and groundwater recharge [3] [4]. Priestley and Taylor [5] suggested to compare ET with equilibrium evapotranspiration (ETeq, defined as evaporation from a wet surface into saturated air) in order to assess the effect of water availability. It is of interest to study the key factors affecting evapotranspiration of vegetation in an ecosystem in the perspective of the key global change issue [6], especially for the seasonal transition periods [7] [8]. Large variability in annual rainfall totals has been observed in the tropics and is thought to be influenced by El Nino-Southern Oscillation (ENSO) and other anomalous circulations [9]-[11]. This in turn affects the amounts of water available for evapotranspiration, affecting local hydrology [12]-[14]. The erratic monsoon was a result of cyclone Aila, which devasted parts of West Bengal and Orissa on May 25, 2009, weakened the monsoon flow. This situation further deteriorated due to the high pressure area over central Asia, which blocked weather systems that brings rain to India, resulting only 77\% rainfall of the long period average (LPA).

Evapotranspiration, just as precipitation, is subject to variability in space and time. And some recent estimates of India's evapotranspiration [15]-[18] are subject to uncertainties and underestimation [19]. During the failure of monsoon with below-normal rainfall evapotranspiration could be in greater magnitude [20], implying correspondingly reduced availability of water amenable for human use. Therefore, the discrepancy of the result in the measurement of India's evapotranspiration merit reconciliation through further studies, considering the importance of the water budget in the nation's natural resource context. India's land area is 3.28 million $\mathrm{km}^{2}$ [21] with varying a real extent, climatic regions, and landscape characteristics. This requires the measurement of evapotranspiration taking into account of spatial and temporal variation in order to integrate the overall estimate, and hence to provide a credible revised estimate of India's evapotranspiration.

Mangrove ecosystem in tropical and sub-tropical environment is water limited ecosystem where the exchange of water between biosphere and atmosphere is restricted to a great extent by monsoonal activities. In the seasonally water-limited systems such as Savana, nature of the biosphere-atmosphere interactions changes during monsoon [22]. In the tropics and sub-tropics, mangrove cover around $1.0 \times 10^{5}$ to $2.3 \times 10^{5} \mathrm{~km}^{2}$ of area and is one of the major ecosystem fringing $60 \%-75 \%$ of the tropical coasts [23]. It is of interest to study the contribution of mangrove to recycle the fraction of total rainfall by evapotranspiration. Attempts have been made here to study the seasonal variation of water vapour exchange in relation to the environmental variables at the landocean boundary of Sundarbans.

\section{Material and Methods}

\subsection{Study Area}

The Indian Sundarban Mangrove forest in the estuarine phase of the river Ganges covers an area of $9630 \mathrm{~km}^{2}$ out of which $4264 \mathrm{~km}^{2}$ is under reserve forest. It is the largest delta on the globe (world's heritage site, whc.unesco.org/en/list/452) and a unique bioclimatic zone for its biodiversity of mangrove flora and fauna both in land and in water at the land-ocean boundary of the Sundarban mangrove forest along the of Bay of Bengal $\left(20^{\circ} 32^{\prime}-20^{\circ} 40^{\prime} \mathrm{N}\right.$ and $\left.88^{\circ} 05^{\prime}-89^{\circ} \mathrm{E}\right)$. This land-ocean boundary is highly irregular and criss-crossed by several rivers and waterways. East to west this area is about $140 \mathrm{~km}$ from the east boundary to the west boundary and 50 $70 \mathrm{~km}$ from the shoreline to the north boundary. There are over 110 discrete islands and low-lying intertidal zones of which 54 have been reclaimed by human population and the remaining 56 are marked for reserve forest including tiger reserve [24]. The islands inside the reserve forest are covered with thick mangrove forest. Height of mangrove plants greater than $10 \mathrm{~m}$ is rare. Mangroves namely Avicennia officinalis, Avicennia alba, Avicennia marina and Aegiceras sp. are the dominant species. Excoecaria agallocha and Heritiera fomes are thinly distributed and Ceriops decandra is found scattered all over the island. Heritiera fomes (locally called Sundari, from which Sundarban derives its name), abundant on the Bangladesh side is not common on the Indian side where it is considered endangered [25]. 
The deltaic soil of Sundarban Biosphere Reserve comprises mainly with saline alluvial soil consisting of clay, silt, fine sand and coarse sand particles.

Mangrove species are grouped together as they share specialized physiological and ecological adaptations to the challenging inter-tidal conditions on tropical and subtropical coasts. "Mangrove" is therefore an ecological grouping rather than reflecting any consistent taxonomic affinity [26].

\subsection{Climate}

Indian climate is a manifestation of the seasonal change in the position of the ITCZ from about $10^{\circ} \mathrm{S}$ over north Indian Ocean in January to about $25^{\circ} \mathrm{N}$, over Asia in July. In the northern winter, the air over Southern Asia is cooler and denser than air over the ocean, and so, the surface atmospheric temperature is greater over the continent than over the ocean, resulting pressure gradient levels to a northerly or northeasterly flow of air from Asia to south of the equator. This flow of air is northeast monsoon. As the year progresses, increased heating weakens the high pressure over Southern Asia. By the northern summer low has developed, so that from May/June to September a southerly or southwesterly wind blows across the region. This is the southwest monsoon (summer monsoon), the stronger of the two monsoons. Four month gap from February to May are called pre-monsoon.

The seasonal climate in Sundarban may be conveniently categorized into pre-monsoon (February to May), monsoon (June to September), post-monsoon (October to January). High humidity prevails ( 98\%) during summer monsoon season. The annual mean maximum and minimum temperature are $31.2^{\circ} \mathrm{C}$ and $13.7^{\circ} \mathrm{C}$, respectively. The total annual rainfall is about 1500 - $2000 \mathrm{~mm}$. Most of the rainfall (about 74\% of the total) occurs during the southwest monsoon period. Cyclonic storms occur sometime in April but frequently associated with monsoon rainfall in July-August. Measurements were carried out at two sites: one located at the Lothian Island (Station 2, $22.420^{\circ} \mathrm{N}$ and $88.420^{\circ} \mathrm{E}$ ) in the confluence of Saptamukhi River and Bay of Bengal, and the other one at Sajnekhali (Station $1,22.117^{\circ} \mathrm{N}$ and $88.82^{\circ} \mathrm{E}$ ) located at a distance of $117 \mathrm{~km}$ from Lothian Island (approximately $38 \mathrm{~km}^{2}$ area) (Figure 1).

To determine any spatial variation within the mangrove forest these two stations were selected near the west

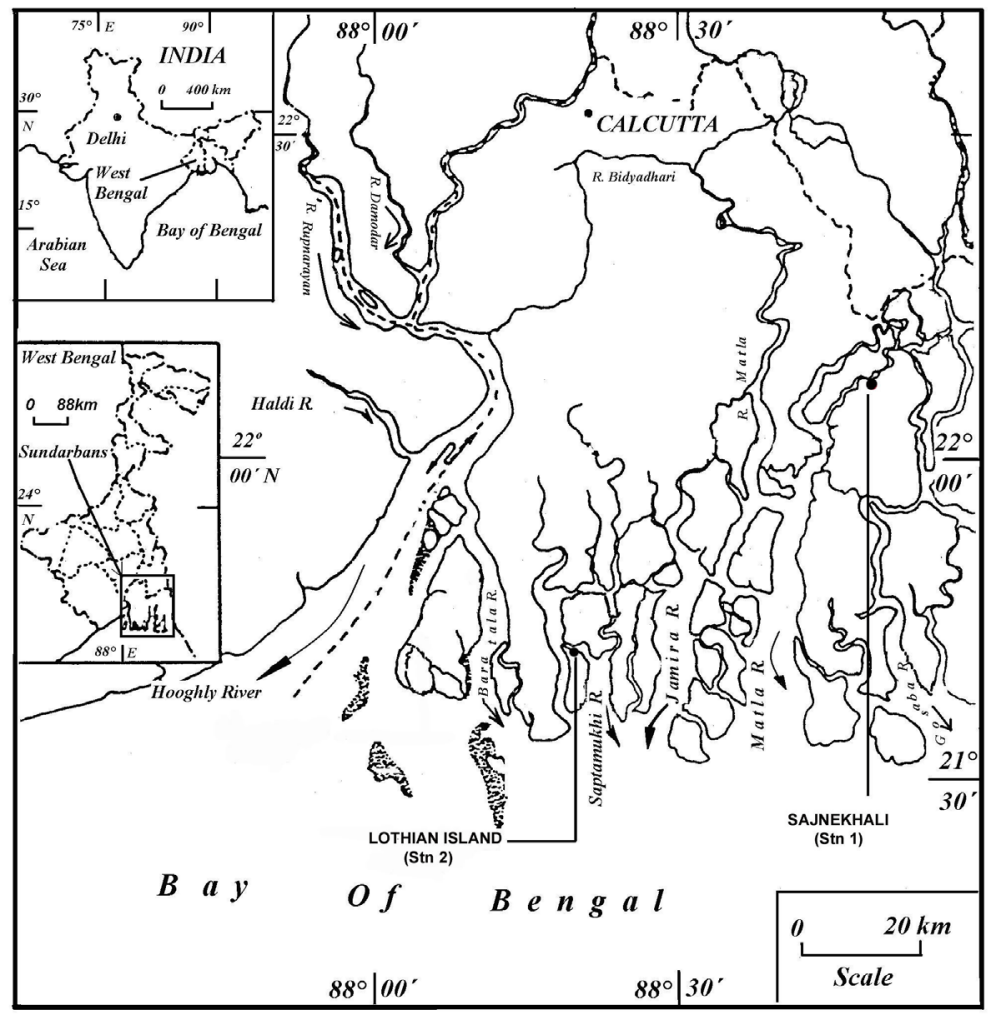

Figure 1. Location of the two selected stations in the Indian Sundarban Mangrove forest. 
ern (Station 2) and eastern margins (Station 1) of Indian Sundarban. In order to measure evapotranspiration and some other related parameter, micrometeorological data were collected from the field. For this purpose two towers were selected, both situated in the midst of a deep forest (fetch up to $10 \mathrm{~km}$ ) so that the true signature of mangrove could be examined. The towers (each about $25 \mathrm{~m}$ tall) over the mangrove forest stands at both sites were used for the measurements at 10 and $20 \mathrm{~m}$. The northern part of Lothian is newly formed and shallow, which is inundated twice a day regularly, whereas the southern part of the island is gradually elevated and inundated only during spring tide.

\subsection{Measurement of Water Vapour and Related Parameters}

Monthly variations of meteorological parameters like air temperature, atmospheric moisture content, atmospheric pressure and wind velocity at these stations were recorded simultaneously at two different heights (10 m and $20 \mathrm{~m}$ ) during 2006-2008 by using probes and an anemometer connected with computerized weather station (Model No. Davis 7440). Climate sensors were scanned in every $5 \mathrm{~min}$ and $1 \mathrm{hr}$ average were recorded.

\subsection{Equations}

Following equations were used to calculate:

a) The partial pressure of water vapour [27]:

$$
P_{\mathrm{H}_{2} \mathrm{O}}=(h / 100) P_{0}
$$

where $h$ is relative humidity.

b) $P_{0}$, vapour pressure of water $(\mathrm{kPa})$ at a given temperature $\left({ }^{\circ} \mathrm{C}\right)[27]$ :

$$
\operatorname{Ln} P_{0}=-0.493048+0.07263769 T-0.000294549 T^{2}+9.79832 \times 10^{-7} T^{3}-1.8653 \times 10^{-9} T^{4}
$$

c) The rate of evapotranspiration $\left(\mathrm{mg} \cdot \mathrm{m}^{-2} \cdot \mathrm{s}^{-1}\right)($ Pal Arya, 2001):

$$
\text { Et or } E=\left[\frac{\rho_{t}}{1.6 \times p} \times \frac{\left[\left(P_{\mathrm{H}_{2} \mathrm{O}(10 \mathrm{~m})}-P_{\mathrm{H}_{2} \mathrm{O}(20 \mathrm{~m})}\right)\right.}{\left(r_{a}+r_{s}\right)}\right]
$$

where, $\rho_{t}$ is the density of air, $p$ is atmospheric pressure. In order to express evapotranspiration in terms of MJ $\mathrm{m}^{-2} \cdot \mathrm{s}^{-1}$, ET $\left(\mathrm{mg} \cdot \mathrm{m}^{-2} \cdot \mathrm{s}^{-1}\right)$ was multiplied by $\lambda$, where $\lambda=$ latent heat of vaporization $=2.45 \mathrm{MJ} \cdot \mathrm{Kg}^{-1}$.

d) Latent heat flux $\left(\mathrm{W} \cdot \mathrm{m}^{-2}\right)[28]$ :

$$
H L=E T \times \lambda
$$

e) Canopy resistance $\left(r_{c}\right)\left(\right.$ in $\left.\mathrm{s} \mathrm{cm}^{-1}\right)$ [29]

$$
r_{c}=\left[\rho_{t} c_{p}\left(e_{s}-e_{d}\right) /(\gamma \times E T)\right]+r_{a}\left[\frac{\Delta}{\gamma\left(\frac{A}{E T}-1\right)}-1\right]
$$

where, $A=$ available energy for evapotranspiration: $\left(R_{n}-H_{G}-H_{s}\right)\left(\mathrm{W} \cdot \mathrm{m}^{-2}\right), c_{p}=$ specific heat of moist air $\left(\mathrm{J} \cdot \mathrm{kg}^{-1} \cdot \mathrm{K}^{-1}\right), e_{s}=$ saturation water vapor pressure at height $d(\mathrm{mb}), e_{d}=$ water vapor pressure at height $d(\mathrm{mb}), R_{N}$ $=$ net solar radiation $\left(\mathrm{W} \cdot \mathrm{m}^{-2}\right), H_{S}=$ storage heat energy $\left(\mathrm{W} \cdot \mathrm{m}^{-2}\right), \Delta=$ slope of the saturation water vapor pressure curve $\left(\mathrm{mb} \cdot \mathrm{K}^{-1}\right), \gamma=$ psychometric constant $\left(66.5 \mathrm{~Pa} \cdot \mathrm{K}^{-1}\right)$.

f) Equilibrium evapotranspiration $\left(E T_{e q}, \mathrm{MJ} \cdot \mathrm{m}^{-2} \cdot \mathrm{d}^{-1}\right)$ defined as evaporation from a wet surface into saturated air [30] and the ratio of sensible $(H)$ and latent heat $\left(H_{L}\right)$ flux (Bowen ratio, $\left.\beta\right)=H / H_{L}[5]$ :

$$
E T_{e q}=\Delta\left(R_{N}-H_{G}\right) /(\Delta+\gamma)
$$

$R_{N}=$ net solar radiation $\left(\mathrm{W} \cdot \mathrm{m}^{-2}\right)$, incoming net short wave radiation $\left(0<R_{N} \leq 4 \mu \mathrm{m}\right)$ was obtained from HY-SPLIT model (http://www.arl.noaa.gov/ready.html).

$H_{G}=$ ground heat flux $\left(\mathrm{W} \cdot \mathrm{m}^{-2}\right), \Delta=$ slope of the saturation water vapour pressure curve $\left(\mathrm{mb} \cdot \mathrm{K}^{-1}\right), \gamma=$ psychrometric constant $\left(66.5 \mathrm{~Pa} \cdot \mathrm{K}^{-1}\right)$ 
g) $r_{a}=$ aerodynamic resistance $\left(\mathrm{s} \cdot \mathrm{cm}^{-1}\right)[31]$ :

$$
r_{a}=\left\{\ln \left(\frac{z}{z^{0}}\right)-\varphi_{c}\right\}\left(k u^{*}\right)^{-1}
$$

where $\varphi_{c}=$ correction function for atmosphere stability [31], $u^{*}=$ frictional velocity.

h) $H$, sensible heat flux $\left(\mathrm{W} \cdot \mathrm{m}^{-2}\right)[28]$

$$
H=\left\{\rho_{t} c_{p}\left(T_{10 \mathrm{~m}}-T_{20 \mathrm{~m}}\right)\right\}\left(r_{a}+r_{s}\right)^{-1}
$$

where $\rho_{t}$ and $c_{p}=$ density and specific heat of air respectively.

$$
\text { i) } r_{s} \text {, surface layer resistance }=B^{-1} /\left(u^{*}\right)
$$

where $B^{-1}=2\left(K / D_{c}\right)^{2 / 3} k^{-1}$, where $k=$ Von Karman constant, $K=$ thermal diffusivity of air, $D_{c}=$ molecular diffusivity [32].

j) $H_{G}$, ground heat flux $\left(\mathrm{W} \cdot \mathrm{m}^{-2}\right)=-K(\mathrm{~d} T / \mathrm{d} z)$

where $K=$ thermal conductivity of soil, $\mathrm{d} T / \mathrm{d} z$ = downward temperature gradient of the soil [28].

k) The slope of the saturation vapour pressure curve: $\Delta=$ slope of the saturation vapour pressure curve $\left(\mathrm{kPa} \cdot{ }^{\circ} \mathrm{C}^{-1}\right)$ at $T_{\text {mean }}:$ [33]:

$$
\Delta=\frac{4098\left[0.6108 \exp \left(17.27 T_{\text {mean }} /\left(T_{\text {mean }}+237.3\right)\right)\right]}{\left(T_{\text {mean }}+237.3\right)^{2}}
$$

$T_{\text {mean }}=$ daily mean air temperature at $2 \mathrm{~m}$ height $\left[{ }^{\circ} \mathrm{C}\right]$.

l) Saturation vapour pressure, $e_{s}$ in $\mathrm{kPa}$ [34]:

$$
e_{s}=\exp [(16.78 T-116.9) /(T+237.3)]
$$

m) Actual vapour Pressure $\left(e_{d}\right)$

$$
e_{d}=e_{s} \times R H / 100
$$

where, $R H=$ relative humidity in percent

n) Vapour Pressure Deficit [35],

$$
V P D=e_{s}-e_{d}
$$

o) Planetary boundary layer [36]

$$
P B L=0.25 u^{*} / f
$$

where, $f$ is Coriolis parameter related to the rotational speed $(\Omega)$ of the earth and latitude $(\varphi)$ as $f=2 \Omega \sin \varphi$.

\section{Result and Discussion}

\subsection{Temperature}

The climate of the Indian subcontinent is dominated by mainly southwest monsoon that causes regular changes in atmospheric temperature, wind speed, direction, rainfall, humidity, air pressure, etc. These changes in the micrometeorological conditions often become the regulating factor behind various biophysical processes in the surface. Highest air temperature at $10 \mathrm{~m}$ height was obtained during May with a mean value of $32.27^{\circ} \mathrm{C} \pm$ $0.85^{\circ} \mathrm{C}$ where as the lowest values were obtained during December with a mean value of $21.51^{\circ} \mathrm{C} \pm 4.57^{\circ} \mathrm{C}(\mathrm{Ta}-$ ble 1). On average the mean annual daytime temperature was recorded $11.4 \%$ higher than that of nighttime. The minimum PBL height of 2095 m was observed during post-monsoon accompanying with the lowest temperature and humidity in the atmosphere compared to that of the monsoon and pre-monsoon. The ratio of roughness length $\left(\mathrm{Z}^{0}=4.91-6.46 \mathrm{~m}\right)$ to the average height of the mangrove plant $\left(\mathrm{h}^{0} \approx 10 \mathrm{~m}\right)$ varied between 0.49 and 0.65. The high roughness length indicates that turbulent mixing did not occur throughout the entire depth of the canopy providing an inefficient surface-atmosphere coupling for the exchange of heat and energy transfer. 
Table 1. Monthly variation of different micrometeorological parameters during the study period (2006-2008). Values are the average of the measurements from the two stations.

\begin{tabular}{|c|c|c|c|c|c|c|c|}
\hline \multirow{2}{*}{$\begin{array}{c}\text { Seasons } \\
2006\end{array}$} & \multicolumn{2}{|c|}{ Temp. $\left({ }^{\circ} \mathrm{C}\right)$} & \multicolumn{2}{|c|}{ Wind (m/sec) } & \multirow{2}{*}{$\begin{array}{c}\begin{array}{c}\text { Humidity } \\
\text { (\%) }\end{array} \\
10 \mathrm{~m}\end{array}$} & \multirow{2}{*}{$\begin{array}{c}\text { Pressure } \\
\mathbf{( m m )} \\
10 \mathrm{~m}\end{array}$} & \multirow[t]{2}{*}{ Wind direction } \\
\hline & $10 \mathrm{~m}$ & $20 \mathrm{~m}$ & $10 \mathrm{~m}$ & $20 \mathrm{~m}$ & & & \\
\hline Pre-monsoon & $29.63 \pm 2.01$ & $28.7 \pm 2.23$ & $2.83 \pm 2.6$ & $4.18 \pm 2.61$ & $80.86 \pm 8.22$ & $754.66 \pm 9.27$ & $25^{\circ}-225^{\circ}$ \\
\hline Monsoon & $29.44 \pm 2.79$ & $28.81 \pm 2.84$ & $1.65 \pm 0.16$ & $2.31 \pm 0.14$ & $88.41 \pm 14.22$ & $755.08 \pm 7.01$ & $135^{\circ}-270^{\circ}$ \\
\hline Post-monsoon & $24.74 \pm 4.70$ & $24.3 \pm 4.51$ & $1.03 \pm 1.25$ & $2.02 \pm 0.97$ & $74.66 \pm 9.88$ & $761.09 \pm 4.63$ & $340^{\circ}-90^{\circ}$ \\
\hline \multicolumn{8}{|l|}{2007} \\
\hline Pre-monsoon & $30.51 \pm 3.94$ & $29.51 \pm 1.58$ & $3.13 \pm 2.18$ & $4.35 \pm 2.34$ & $83.39 \pm 7.9$ & $754.42 \pm 9.12$ & $25^{\circ}-225^{\circ}$ \\
\hline Monsoon & $29.80 \pm 2.51$ & $29.13 \pm 4.69$ & $1.39 \pm 0.46$ & $1.97 \pm 0.84$ & $89.13 \pm 9.84$ & $756.51 \pm 8.88$ & $135^{\circ}-270^{\circ}$ \\
\hline Post-monsoon & $23.31 \pm 4.68$ & $22.35 \pm 5.86$ & $1.25 \pm 0.92$ & $2.06 \pm 0.91$ & $75.03 \pm 7.14$ & $759.85 \pm 7.7$ & $340^{\circ}-90^{\circ}$ \\
\hline \multicolumn{8}{|l|}{2008} \\
\hline Pre-monsoon & $30.42 \pm 2.88$ & $29.51 \pm 2.24$ & $3.61 \pm 2.36$ & $4.76 \pm 2.85$ & $81.82 \pm 9.12$ & $754.37 \pm 4.46$ & $25^{\circ}-225^{\circ}$ \\
\hline Monsoon & $29.92 \pm 2.60$ & $29.28 \pm 4.82$ & $1.37 \pm 1.8$ & $2.13 \pm 2.08$ & $83.24 \pm 10.32$ & $755.99 \pm 8.88$ & $135^{\circ}-270^{\circ}$ \\
\hline Post-monsoon & $22.91 \pm 4.32$ & $22.01 \pm 4.69$ & $0.81 \pm 0.38$ & $1.68 \pm 0.15$ & $72.45 \pm 5.91$ & $761.64 \pm 6.36$ & $340^{\circ}-90^{\circ}$ \\
\hline
\end{tabular}

A diurnal maximum temperature difference of $13.0^{\circ} \mathrm{C}$ was observed in December and a minimum of $3.9^{\circ} \mathrm{C}$ in June. Though inversion of temperature was observed in the mangrove forest in the midnight between 00:00 and 04:00 h during pre-monsoon and post-monsoon seasons, it was a rare phenomenon in the monsoon.

\subsection{Wind and Pressure}

Annual shift of ITCZ in the tropical mangrove forest (e.g. Sundarban) results a significant change in wind direction, velocity and composition. This could cause seasonality in the mixing ratios of various trace gases in the mangrove environment. Southwest monsoon was more intense with respect to its extreme character relative to the north-east monsoon in this micro-climatic region. Highest wind speed was recorded during April with a mean value of $5.37 \pm 0.78 \mathrm{~m} \cdot \mathrm{s}^{-1}$ (Table 1 ). The onset of post-monsoon brings relatively cool and calm condition with lesser humidity in the air in this climatic zone. The average atmospheric pressure ranged between 748.5 and $763.68 \mathrm{~mm}$ Hg with few low pressures spells from May to August. Diurnal distribution of wind velocity showed two peaks, the first around 12:00 hr local time and the second around late night time.

The wind in the lower atmosphere plays a major role in regulating various bio-physical processes both in terrestrial as well as aquatic ecosystems. It exerts a force on the surface over which it blows, it is effective in transporting heat and material from the surface and it is highly variable in space and time.

Direction of wind changes with seasons. During the pre-monsoon the wind was blown both from the land and seaward direction within the range of 25 - 600 (northeast) $-90^{\circ}$ (east)-225 (southwest). Humid wind was blown consistently from the seaward direction which ranged between $135^{\circ}$ and $270^{\circ}$ (southeast to southwest) throughout the months of monsoon. In the months of post-monsoon wind was mainly blown from the landward direction, which ranged between $270^{\circ}$ (west)-315-345 (northwest)-60-90 (northeast-east) (Table 1). The dry wind blowing from the landward direction supports advective transport of different pollutants (including different trace gases) to the mangrove atmosphere. Land breeze-sea breeze phenomenon was present only in the months of post-monsoon and early pre-monsoon. Rest part of the year this phenomenon was totally suppressed by monsoonal wind.

The mangrove atmosphere remained unstable [stable condition is for $0<z / L<1$ and $0>z / L>-1$ is unstable condition], which favored turbulent mixing and transport of both heat and momentum within the boundary layer for most part of the year. Few spells of atmospheric stability were recorded all of which were observed during the nighttime of late post-monsoon and pre-monsoon seasons. 


\subsection{Humidity}

Due to the presence of the open ocean near these sampling stations the humidity values did not vary very much and the monthly mean humidity never went below $60 \%$ throughout the year. The humidity was at a higher range (84.17\% - 96.39\%) during the monsoon than in the pre- $(76.47 \%$ - $77.95 \%)$ and post-monsoon $(69.56 \%$ 79.95\%). Intensity and availability (seasonal) of solar radiation control the humidity of the troposphere. The diurnal pattern of humidity showed higher variation during the months of post-monsoon in consistence with temperature relative to that of rest of the seasons.

\subsection{Rainfall}

Sundarban mangrove ecosystem regularly experiences a large amount of rainfall, which is mainly attributed to the monsoon starting from June, and extends up to September (sometimes up to October) of every year. This southwest monsoon carries a huge amount of humid air from the ocean to the terrestrial area, causing substantial rainfall in this Indian subcontinent. Monthly rainfall data for the study area was collected from the Indian Meteorological Department (http://www.imd.gov.in/). Highest annual rainfall was recorded in 2007 with a value of $2252.9 \mathrm{~mm}$. On the other hand the year 2008 was the driest during the study period with a yearly rainfall value of $1622.3 \mathrm{~mm}$. The post-monsoon season (October to January) was relatively dry (due to the north-east monsoon carrying cold and dry air from the terrestrial land mass) with respect to the rest of the year. There was almost no rainfall recorded in December during the study period.

\subsection{Evapotranspiration}

Daily incoming short wave radiation ranged from 0 (night time minimum) to $688 \mathrm{~W} \cdot \mathrm{m}^{-2}$ (day time maximum) during the measurement period with an annual daytime mean of $435 \pm 32.8 \mathrm{~W} \cdot \mathrm{m}^{-2}$. The distribution of incoming net short wave radiation was found to be $0.29 R_{N}$ for sensible, $0.35 R_{N}$ for latent heat, $0.04 R_{N}$ for ground heat flux, suggesting that latent heat flux greater than the sensible heat flux $(\mathrm{H})$ [35] [36]. Latent heat flux showed significant positive correlation with $\mathrm{R}_{\mathrm{N}}\left(\mathrm{HL}=0.1738 \mathrm{R}_{\mathrm{N}}+61.418, \mathrm{R}^{2}=69.5 \%, \mathrm{p}<0.01\right.$ for the pre-monsoon, $\mathrm{HL}=0.2119 \mathrm{R}_{\mathrm{N}}+67.684, \mathrm{R}^{2}=71 \%, \mathrm{p}<0.001$ for the monsoon, $\mathrm{HL}=0.153 \mathrm{RN}+81.455, \mathrm{R}^{2}=61 \%, \mathrm{p}<0.01$ for the post-monsoon). Average annual precipitation $(\mathrm{P})$ was $2065 \pm 194.1 \mathrm{~mm}$, of which around $87 \%$ occurred from June to October (Monsoon). Total evapotranspiration during monsoon months were estimated to be 477.57 $\mathrm{mm}$ with a rate $0.055 \mathrm{~g} \cdot \mathrm{m}^{-2} \cdot \mathrm{s}^{-1}$ which was greater than in the post-monsoon $\left(469.44 \mathrm{~mm}\right.$ and $\left.0.040 \mathrm{~g} \cdot \mathrm{m}^{-2} \cdot \mathrm{s}^{-1}\right)$ and the post-monsoon (457.58 and $0,044 \mathrm{~g} \cdot \mathrm{m}^{-2} \cdot \mathrm{s}^{-1}$ ) (Figure 2 and Figure 3). The ratio of ET to P (67.7\%) at the land ocean boundary demonstrated that the magnitudes of ET and P were not equal on an annual basis. This ratio is low as compared with that of steppe in central Mongolia (79\% - 94\%) [37], and that for a steppe close to the edge of the Eurasian cryosphere in Mongolia (94\%) [38] [39]. However, the ET to P ratio in this study was found to be close to the ratios reported for annual grassland in the State California (54\% - 59\%) [40] and for the Montane grasslands of South Africa (40\% - 76\%) [41]. The estimates for evapotranspiration for different regions of the world vary between $59.4 \%$ and $90 \%$ [42]-[49]. Less evapotranspiration from the Sundarban mangrove sur-

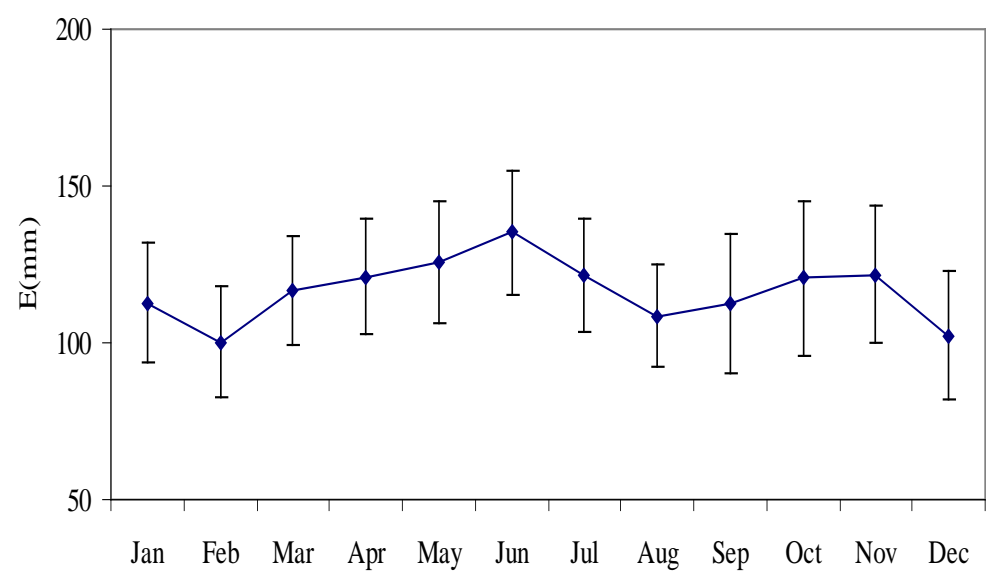

Figure 2. Monthly mean evapotranspiration at Sundarban mangrove forest. 


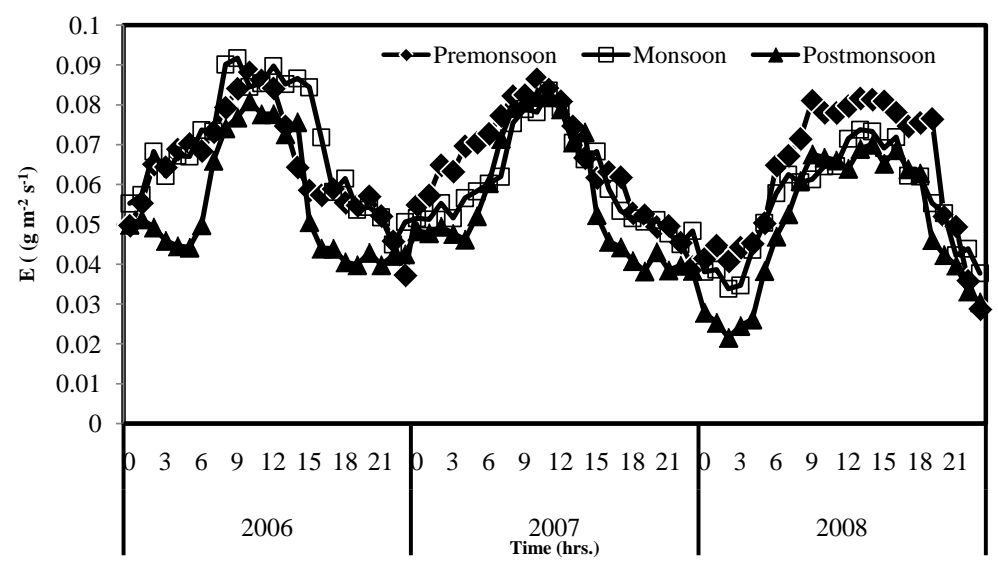

Figure 3. Diurnal variation of evapotranspiration (E) in three different seasons during the study period (2006-2008) at Sundarban mangrove ecosystem.

face was reported during winter (north east monsoon) when cool and dry wind (with relatively lower wind velocity, temperature and humidity compared to monsoon and pre-monsoon) blows over the forest canopy irrigated with warm tidal water.

Diurnal pattern of evaporation rate during three different seasons at Sundarban mangrove ecosystem (Figure 3) showed daytime maximum with about 52\% reduction during nighttime. Daley et al. [50] obtained 50\% decrease of transpiration rate relative to that of daytime for paper Brich forest. Nighttime transpiration rates (Enight) varied from 5\% to $15 \%$ of daytime rates with a maximum of 30\% for irrigated Eucalyptus grandis plantation [51]-[54].

Evaporation is controlled both by the amount of available energy and plant physiological activity (i.e. stomata opening and closing). Transpiration is insignificant at night when stomata remain closed. However, stomata of some species could remain open at night, for nighttime transpiration driven by environmental forcing.

\subsection{Vapour Pressure Deficit}

Vapour pressure deficit (VPD) is one of the major criteria of plant growth. As a general rule, most plants grow well at VPD values of between 0.8 to $0.95 \mathrm{kPa}$ [55]. In the Sundarban Mangrove forest mean annual distribution of VPD curve followed the trend of water availability and diurnal solar radiation all over the year. In the daytime VPD was regulated by atmospheric temperature. VPD values ranged from 0.093 to $2.17 \mathrm{kPa}$ all over the year in this ecosystem with a maximum during post-monsoon season (Figure 4). In spite of lower temperature intrusion of dry northeast monsoonal wind from the landward direction to the mangrove environment could be the reason behind the higher values of VPD during the post-monsoon period.

\subsection{Canopy Resistance}

The canopy resistance $r_{c}$, is the resistance of all stomata of the leaves and depend primarily on solar radiation, vapour pressure deficit and soil moisture deficit. Canopy resistance $\left(r_{c}\right)$ is one of the important factors controlling biosphere-atmosphere exchange of water vapour [56]-[58] apart from $r_{a}$ (aerodynamic resistance) and $r_{s}$ (surface layer resistance). A typical steady increase in the forest canopy resistance during daytime hours was observed (Figure 5). Annual daytime and nighttime mean of canopy resistance was found to be 1.78 and 0.68 $\mathrm{s} \cdot \mathrm{cm}^{-1}$ respectively in this mangrove forest. The highest value was obtained during the daytime $\left(3.4 \mathrm{~s} \cdot \mathrm{cm}^{-1}\right)$ in the pre-monsoon whereas the lowest value was recorded $0.045 \mathrm{~s} \cdot \mathrm{cm}^{-1}$ at night in the monsoon period. During the monsoon, the $r_{c}$ values were recorded lower both in the day and night time compared to that of pre-monsoon and post-monsoon. The low value of canopy resistance in the morning $\left(1-2 \mathrm{~s}^{\cdot} \mathrm{cm}^{-1}\right)$ and its steady increase during the $\left(4 \mathrm{~s} \cdot \mathrm{cm}^{-1}\right)$ daytime from Douglas-fir forest was also observed by McNaughton and Black [57]. Similar daytime courses of canopy resistance have been reported by Stewart and Thorn [56] and Gash and Stewart [58] for a pine forest with high values of soil water potential. A significant negative correlation was found between canopy resistance and relative humidity (Figure 6). 


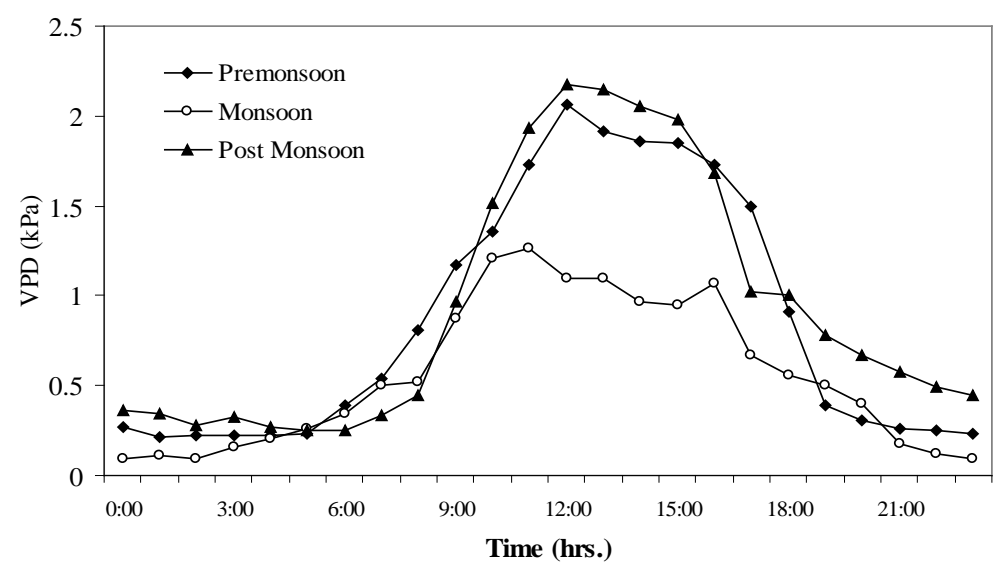

Figure 4. Diurnal variation of VPD in three different seasons at Sundarban mangrove ecosystem.

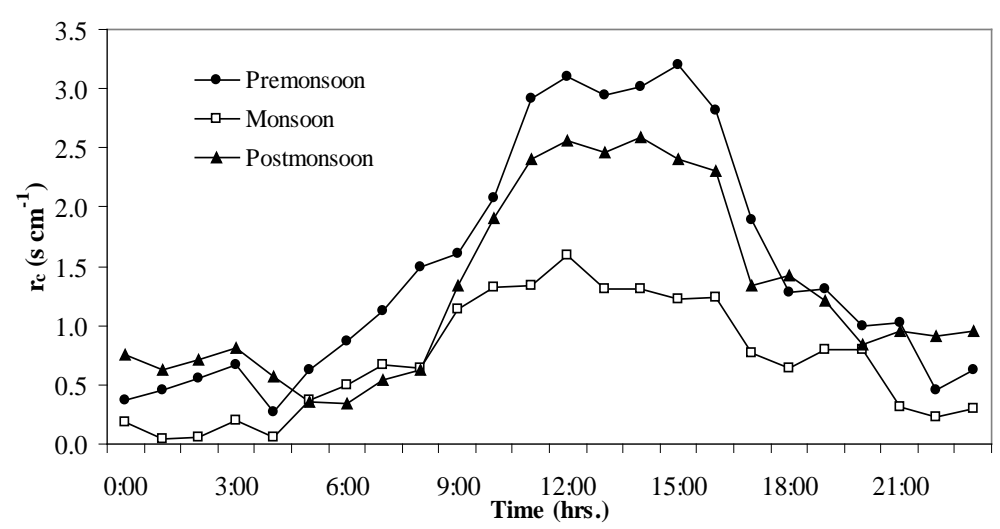

Figure 5. Diurnal variation of canopy resistance in three different seasons at Sundarban mangrove ecosystem.

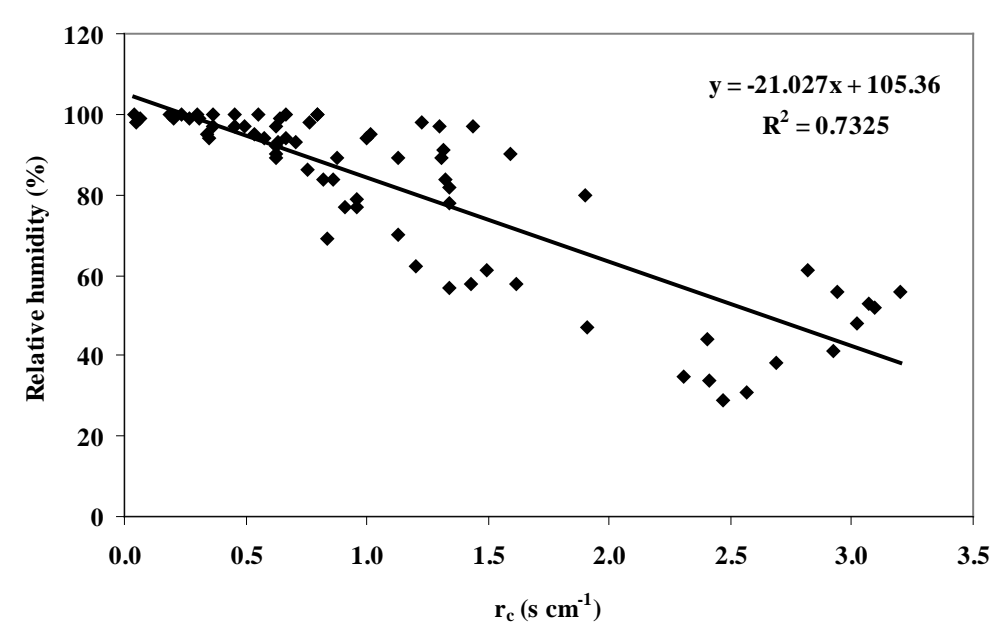

Figure 6. Correlation between canopy resistance and relative humidity at Sundarban mangrove ecosystem.

Figures 7(a)-(c) depict the correlation between ETeq and measured ET and significant correlations in all the seasons were obtained. The relative transpiration rate (ET/ETeq) (i.e. actual to equilibrium) varied between 0.92 $\pm 0.32,0.79 \pm 0.33$ with a maximum value during monsoon and Price and Woo [59] Thompson et al. [60] sug- 
gested that a canopy could have a greater transpiration rate in wet condition than that of a dry condition.

The ratio ET/ETeq known as Priestley-Taylor parameter exhibited a negative relation with canopy resistance (Figure 8), indicating greater canopy resistance while there was limited water availability at low ET/ETeq.

\section{Conclusion}

This study reports on temporal variation of water vapour mixing ratio in the atmosphere and its exchange rate in the Sundarbans mangrove biosphere. The magnitude and dynamics of evapotranspiration (ET) exhibited seasonality dominated by monsoon and annually $67.7 \%$ of total precipitation was consumed by evapotranspiration. During the wet season (monsoon), the mean evapotranspiration rate was $0.055 \pm 0.015 \mathrm{~g} \cdot \mathrm{m}^{-2} \cdot \mathrm{s}^{-1}$ and was $12 \%$ -

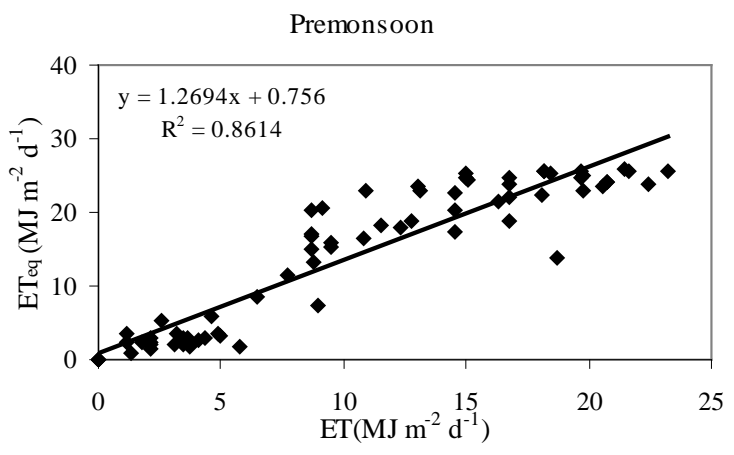

(a)

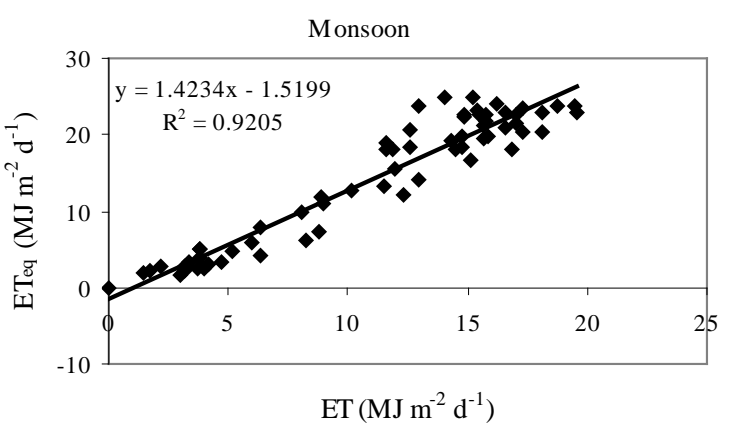

(b)

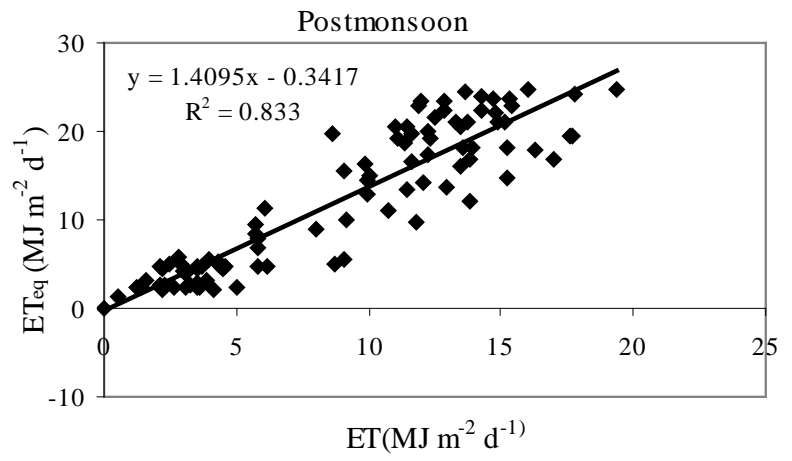

(c)

Figure 7. The correlation between ET and ETeq in (a) pre-monsoon; (b) monsoon; (c) post-monsoon, at Sundarban mangrove ecosystem.

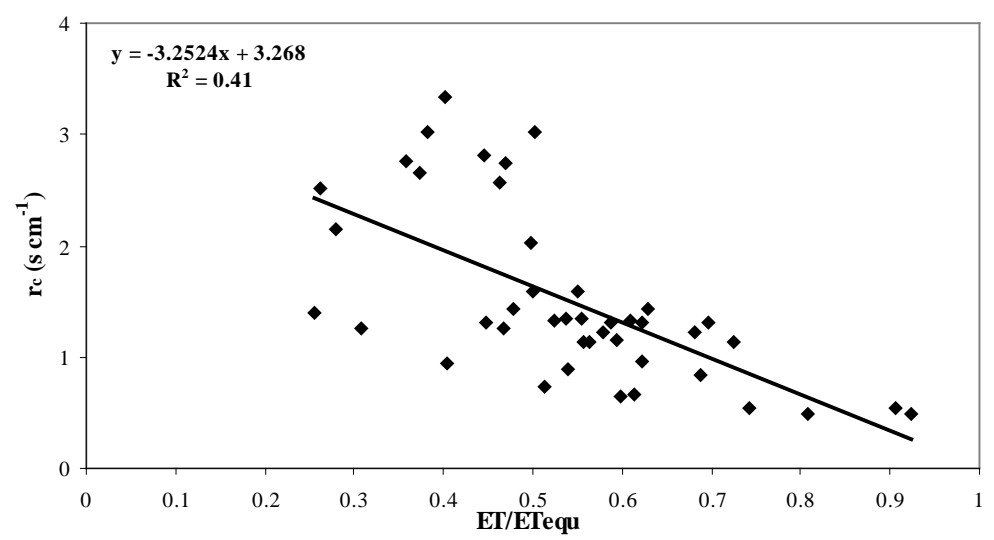

Figure 8. Correlation between ET/ETeq and canopy resistance of mangrove forest, at Sundarban. 
$25 \%$ higher than during the dry season (pre- and post-monsoon). There seems to be significant impact of the monsoonal period on canopy resistance. Evapotranspiration in the mangrove forest seems to be controlled by the monsoonal cycle in association with plant physiological activity (i.e. stomata opening and closing).

\section{Acknowledgements}

Authors are indebted to the DST, Government of India, for providing the grant. Thanks are due to Sundarban Biosphere Reserve and Divisional forest office, South 24 Parganas, Goverment of West Bengal for giving permissions to carry out the study.

\section{References}

[1] Pallardy, S.G. (2007) Physiology of Woody Plants. Academic Press, Waltham.

[2] Baumgartner, A. and Reichel, E. (1975) World Water Balance: Mean Annual Global, Continental and Maritime Precipitation, Evaporation and Run-Off. Elsevier, Amsterdam.

[3] Kurc, S.A. and Small, E.E. (2004) Dynamics of Evapotranspiration in Semiarid Grassland and Shrubland Ecosystems during the Summer Monsoon Season, Central New Mexico. Water Resources Research, 40, Article ID: W09305. http://dx.doi.org/10.1029/2004WR003068

[4] Decker, J.P., Gaylor, W.G. and Cole, F.D. (1962) Measuring Transpiration of Undisturbed Tamarisk Shrubs. Plant Physiology, 37, 393-397. http://dx.doi.org/10.1104/pp.37.3.393

[5] Priestley, C.H.B. and Taylor, R.J. (1972) On the Assessment of Surface Heat Flux and Evaporation Using Large Scale Parameters. Monthly Weather Review, 100, 81-92. http://dx.doi.org/10.1175/1520-0493(1972)100<0081:OTAOSH>2.3.CO;2

[6] Law, B.E., Falge, E. and Gu, L. (2002) Environmental Controls over Carbon Dioxide and Water Vapor Exchange of Terrestrial Vegetation. Agricultural and Forest Meteorology, 113, 97-120. http://dx.doi.org/10.1016/S0168-1923(02)00104-1

[7] Kellomaki, S. and Wang, K. (1999) Short-Term Environmental Controls of Heat and Water Vapor Fluxes above a Boreal Coniferous Forest: Model Computations Compared with Measurements by Eddy Correlation. Ecological Modelling, 24, 145-173. http://dx.doi.org/10.1016/S0304-3800(99)00159-3

[8] Barford, C.C., Wofsy, S.C. and Goulden, M.L. (2001) Factors Controlling Long- and Short-Term Sequestration of Atmospheric $\mathrm{CO}_{2}$ in a Mid-Latitude Forest. Science, 294, 1688-1691. http://dx.doi.org/10.1126/science.1062962

[9] McKinley, G.A., Follows, M.J. and Marshall, J. (2004) Mechanisms of Air-Sea $\mathrm{CO}_{2}$ Flux Variability in the Equatorial Pacific and the North Atlantic. Global Biogeochemical Cycles, 18, 2011-2025. http://dx.doi.org/10.1029/2003GB002179

[10] Malhi, Y. and Wright, J. (2004) Spatial Patterns and Recent Trends in the Climate of Tropical Rainforest Regions. Philosophical Transactions of Royal Society London Series B, 359, 311-329. http://dx.doi.org/10.1098/rstb.2003.1433

[11] Bousquet, P., Peylin, P., Ciais, P., Le Quere, C. and Friedlingstein, P.P. (2000) Tans, Regionial Changes in Carbondioxide Fluxes of Land and Oceans since 1980. Science, 290, 1342-1346. http://dx.doi.org/10.1126/science.290.5495.1342

[12] da Rocha, H.P., Goulden, M.L., Miller, S.D., Menton, M.C., Pinto, L.D.V.O., de Freitas, H.C. and Silva Figueira, A.M.E. (2004) Seasonality of Water and Heat Fluxes over a Tropical Forest in Eastern Ammazonia. Ecological Applications, 14, 822-832. http://dx.doi.org/10.1890/02-6001

[13] Malhi, Y., Pegoraro, F., Nobre, A.D., Pereira, M.G.P., Grace, J., Culf, A.D. and Clement, R. (2002) Energy and Water Dynamics of a Central Amazonian Rain Forest. Journal of Geophysical Research, 107. http://dx.doi.org/10.1029/2001JD000623

[14] Shuttleworth, W.J., Sash, H.C., Lloyd, C.R., Moore, C.J., Roberts, J., Marques Filho, A.D.O., Fisch, G., Silva Fillro, V.D.P., Nobre, I.C.A., Cabral, O.M.R., Paiel, S.R. and Moraes, J.C. (1984) Eddy Correlation Measurements of Energy Partition for Amazonia Forest. Quarterly Journal of the Royal Meteorological Society, 110, 1143-1163. http://dx.doi.org/10.1002/qj.49711046622

[15] Gupta, S.K. and Deshpande, R.D. (2004) Water for India in 2050: First Order Assessment of Available Options. Current Science, 86, 1216-1224.

[16] Kumar, R., Singh, R.D. and Sharma, K.D. (2005) Water Resources of India. Current Science, 89, 794-811.

[17] Garg, N.K. and Hassan, Q. (2007) Alarming Scarcity of Water in India. Current Science, 93, 932-941.

[18] Planning Commisson (2007) Report of the Expert Group on Ground Water Management and Ownership. Government of India, New Delhi. 
[19] Narasimhan, T.N. (2008) A Note of India’s Water Budget and Evapotranspiration. Journal of Earth System Science, 117, 237-240. http://dx.doi.org/10.1007/s12040-008-0028-8

[20] Jain, S.K., Agarwal, P.K. and Singh, V.P. (2007) Hydrology and Water Resources of India. Springer, Dordrecht, 1258.

[21] National Circumstances (2004) India’s Initial National Communication to the United Nations Framework Convention on Climate Change, Chapter-1. 3-28. http://unfccc.int/resource/docs/natc/indnc1.pdf

[22] Hutley, L.B., Grady, A.P.O. and Eamus, D. (2001) Monsoonal Influence on Evapotranspiration of Savanna Vegetation of Northern Australia. Oecologia, 26, 434-443. http://dx.doi.org/10.1007/s004420000539

[23] Clough, B. (1998) Mangrove Forest Productivity and Biomass Accumulation in Hinchinbrook Channel, Australia. Mangroves and Salt Marshes, 2, 191-198. http://dx.doi.org/10.1023/A:1009979610871

[24] Chakrabarty, K. (1987) Sundarban Mangrove in India-A Study of Conservation Status. Indian Forest, 113, $352-358$.

[25] Gopal, B. and Chauhan, M. (2006) Biodiversity and Its Conservation in the Sundarban Mangrove Ecosystem. Aquatic Sciences, 68, 338-354. http://dx.doi.org/10.1007/s00027-006-0868-8

[26] Alongi, D.M. and Robertson, A.I. (1995) Factors Regulating Benthic Food Chains in Tropical River Deltas and Adjacent Shelf Areas. Geo-Marine Letters, 15, 145-152. http://dx.doi.org/10.1007/BF01204456

[27] Millero, F.J. (1996) Chemical Oceanography. 2nd Edition, CRC Press, New York.

[28] Arya, S.P. (2001) Introduction to Micrometeorology. Academic Press, New York.

[29] Tan, C.S. and Black, T.A. (1976) Factors Affecting the Canopy Resistance of a Douglas-Fir Forest. BLM, 475-488.

[30] Priestley, C.H.B. (1959) Turbulent Transfer in the Lower Atmosphere. University of Chicago Press, Chicago.

[31] Wesely, M.L. and Hicks, B.B. (1977) Some Factors That Affect the Deposition Rates of Sulfur Dioxide and Similar Gases on Vegetation. Journal of the Air Pollution Control Association, 27, 1110-1116. http://dx.doi.org/10.1080/00022470.1977.10470534

[32] Bodek, I., Lyman, W.J., Reehl, W.F. and Rosenblatt, D.H. (1988) Environmental Inorganic Chemistry. Pergamon Press, Oxford.

[33] Allen, G.R., Pereira, L.S., Raes, D. and Smith, M. (1998) Crop Evapotranspiration, Food and Agriculture Organization (FAO) of the United Nations, 8.

[34] Ward, A.D., Trimble, S.W. and Wolman, M.G. (2004) Environmental Hydrology. 2nd Edition, Lewis Publishers, Boca Raton, Florida.

[35] Barr, D., Barr, J.G., Fuentes, J.D., Zieman, J.C., Grahl, T. and Childars, D. (2005) Seasonal Controls on Energy Partitioning Patterns of a Mangrove Forest, FCE LTER. All Scientists Meeting, 25-26 March 2005.

[36] Ganguly, D., Dey, M., Mandal, S.K., De, T.K. and Jana, T.K. (2008) Energy Dynamics and Its Implication to Biosphere-Atmosphere Exchange of $\mathrm{CO}_{2}, \mathrm{H}_{2} \mathrm{O}$ and $\mathrm{CH}_{4}$ in a Tropical Mangrove Forest Canopy. Atmospheric Environment, 42, 4172-4184. http://dx.doi.org/10.1016/j.atmosenv.2008.01.022

[37] Miyazaki, S., Yasunari, T., Miyamoto, T., Kaihotsu, I., Davaa, G., Oyunbaatar, D., Natsagdorj, L. and Oki, T. (2004) Agrometeorological Conditions of Grassland Vegetation in Central Mongolia and Their Impact for Leaf Area Growth. Journal of Geophysical Research: Atmospheres, 109, Published Online. http://dx.doi.org/10.1029/2004JD005179

[38] Zhang, Y., Munkhtsetseg, E., Kadota, T. and Ohata, T. (2005) An Observational Study of Ecohydrology of a Sparse Grassland at the Edge of the Eurasian Cryosphere in Mongolia. Journal of Geophysical Research: Atmospheres, 110, Published Online. http://dx.doi.org/10.1029/2004JD005474

[39] Li, S.G., Asanuma, J., Kotani, A., Davaa, G. and Oyunbaatar, D. (2007) Evapotranspiration from a Mongolian Steppe under Grazing and Its Environmental Constraints. Journal of Hydrology, 333, 133-143. http://dx.doi.org/10.1016/j.jhydrol.2006.07.021

[40] Baldocchi, D.D., Xu, L. and Kiang, N. (2004) How Plant Functional-Type, Weather, Seasonal Drought and Soil Physical Properties Alter Water and Energy Fluxes of an Oak-Grass Savanna and an Annual Grassland. Agricultural and Forest Meteorology, 123, 13-39. http://dx.doi.org/10.1016/j.agrformet.2003.11.006

[41] Everson, C.S. (2001) The Water Balance of a First Order Catchment in the Montane Grasslands of South Africa. Journal of Hydrology, 241, 110-123.

[42] Shiklomanov, I.A. (1997) Comprehensive Assessment of the Freshwater Resources of the World. World Meteorological Organization, Stockholm, 88.

[43] Australian Water Resources (2005) Water Availibility, Australian Water Resources. http://www.water.gov.au/WaterAvailability/

[44] Marengo, J.A. (2006) On the Hydrological Cycle of the Amazonbasin: A Historical Review and Current State-of-theArt. Revista Brasileira de Meteorologia, 21, 1-19.

[45] Berbery, E.H. and Barros, V.R. (2002) The Hydrological Cycle of the La Plata Basin in South America. Journal of 
Hydrometeorology, 3, 630-645. http://dx.doi.org/10.1175/1525-7541(2002)003<0630:THCOTL>2.0.CO;2

[46] Institut Francais de L'Environment (2004) L'e/tat des eaux souterraines en France, aspects quentitatifs et qualitatifs. Report, Institut francais de l'environment, Orle/ans, Etudes et Travaux n043, 34.

[47] Department of Water Resources, State California (2005) Water Plan Update 2005, Public Review Draft, Vol. 3.

[48] Loescher, H.W., Gholz, H.L., Jacobs, J.M. and Oberbauer, S.F. (2005) Energy Dynamics and Modeled Evapotranspiration from a Wet Tropical Forest in Costa Rica. Journal of Hydrology, 315, 274-294.

[49] Leopold, L.B. (1974) Water: A Primar. W. H. Freeman, San Francisco, 172.

[50] Daley, M.J. and Phillips, N.G. (2006) Interspecific Variation in Nighttime Transpiration and Stomatal Conductance in a Mixed New England Deciduous Forest. Tree Physiology, 26, 411-419. http://dx.doi.org/10.1093/treephys/26.4.411

[51] Benyon, R. (1999) Nighttime Water Use in an Irrigated Eucalyptus grandis Plantation. Tree Physiology, 19, 853-859. http://dx.doi.org/10.1093/treephys/19.13.853

[52] Snyder, K.A., Richards, J.H. and Donovan, L.A. (2003) Night-Time Conductance in C3 and C4 Species: Do Plants Lose Water at Night? Journal of Experimental Botany, 54, 861-865.

[53] Bucci, S.J., Scholz, F.G., Goldstein, G., Meinzer, F.C., Hinojosa, J.A., Hoffman, W.A. and Franco, A.C. (2004) Processes Preventing Nocturnal Equilibration between Leaf and Soil Water Potential in Tropical Savanna Woody Species. Tree Physiology, 24, 1119-1127. http://dx.doi.org/10.1093/treephys/24.10.1119

[54] Scholz, F.G., Bucci, S.J., Goldstein, G., Meinzer, F.C., Franco, A.C. and Miralles-Wilhelm, F. (2007) Removal of Nutrient Limitations by Long-Term Fertilization Decreases Nocturnal Water Loss in Savanna Trees. Tree Physiology, 27, 551-559. http://dx.doi.org/10.1093/treephys/27.4.551

[55] Autogrow Systems Ltd. Web Site, Humidity Page.

[56] Stewart, J.B. and Thorn, A.S. (1973) Energy Budgets in a Pine Forest. Quarterly Journal of the Royal Meteorological Society, 99, 154-170. http://dx.doi.org/10.1002/qi.49709941913

[57] McNaughton, K.G. and Black, T.A. (1973) A Study of Evapotranspiration from a Douglas-Fir Forest Using the Energy Balance Approach. Water Resources Research, 9, 1579-1590. http://dx.doi.org/10.1029/WR009i006p01579

[58] Gash, J.H.C. and Stewart, J.B. (1975) The Average Surface Resistance of a Pine Forest Derived from Bowen-Ratio Measurements. BLM, 8, 453-464.

[59] Price, J.S. and Woo, M.K. (1988) Studies of a Subarctic Coastal Marsh. Journal of Hydrology, 103, 275-292.

[60] Thompson, M.A., Campbell, D.I. and Spronken-Smith, R.A. (1999) Evaporation from Natural and Modified Raised Peat Bogs in New Zealand. Agricultural and Forest Meteorology, 95, 85-98.

http://dx.doi.org/10.1016/S0168-1923(99)00027-1 
Scientific Research Publishing (SCIRP) is one of the largest Open Access journal publishers. It is currently publishing more than 200 open access, online, peer-reviewed journals covering a wide range of academic disciplines. SCIRP serves the worldwide academic communities and contributes to the progress and application of science with its publication.

Other selected journals from SCIRP are listed as below. Submit your manuscript to us via either submit@scirp.org or Online Submission Portal.
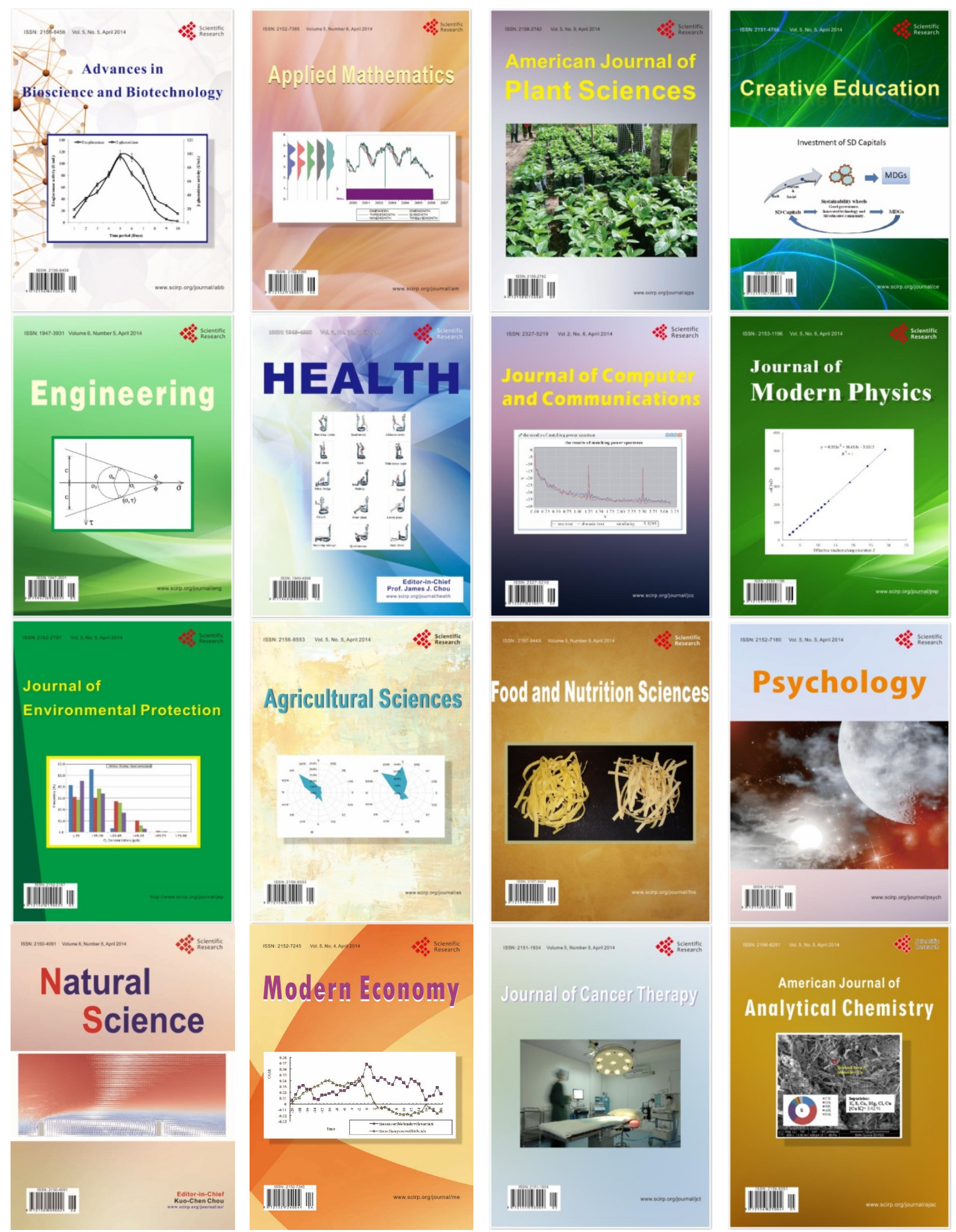